\title{
The Evacuation of the Idomeni Refugee Camp: A Case of Discursive and Iconographical Representation on Digital Media
}

\author{
By Andrea Pelliccia*
}

\begin{abstract}
By using the Multimodal Critical Discourse Analysis, this paper focuses on the visual and textual representation of refugees in the online version of two influential newspapers in Greece. The analysis examines the particularities and significance of news coverage of a critical event in Greece and Europe during 2016 that is the evacuation of the Idomeni refugee camp. The results show that in the media representation of refugees and asylum seekers, cultural clichés and the perpetuation of an essentialist discourse emerge systematically in a vicious circle. Through their representational frames, both newspapers reveal a tendency to more a homogenization of views and explanations than to provide a plurality of opinions. Using an institutional and generalist approach based on monodimensional formats, they thus contribute to perpetuating a dispositive suitable for pre-existing social representations and stereotypes.
\end{abstract}

Keywords: Idomeni refugee camp, migrants' representation, online newspapers, refugee crisis.

\section{Introduction: Research Objective and Methodological Approach}

The choice of online media is due to the fact that they are now part of the social, economic and cultural life of many societies, and are accessible to public, and are different from print-based newspapers, while reaching a younger audience (Newman et al. 2016). On the one hand, online newspapers tend to reproduce journalism culture of printed newspapers with their approach to storytelling, in values and relationship with readers. On the other hand, technological features of online platform - hypertext, interactivity, multimedia - have implications for the entire media production process (Deuze 2003): electronic consultation - due to the variety of textual typologies, consultation modes, and contextual elements configures a new and specific system compared to paper-based newspapers. Furthermore, journalism has always been influenced by technology (Pavlik 2001). Online newspapers are publishing products often parallel and complementary to printed products. In addition to the fixed texts - which usually are a minority they include a variety of modal texts ranging from images to videos and photo galleries linked by various hyperlinks and which reproduce traces of ancient orality (Ong 1982). Just think of the polyphonic dimension that allows for a great fluidity in communicative interaction and non-fixity of the content. Not always, in fact, it is possible to trace a hierarchy of content similar to the one found on the

${ }^{*}$ Researcher, Institute for Research on Population and Social Policies, National Research Council of Italy, Italy. 
homepages of the newspapers, not only for frequent changes to the homepages but also for the "horizontal" transmission via social networks by readers (Kopper et al. 2000). It is true that online journalism has been defined as a "fourth" type of journalism, alongside printed newspapers, radio and television (Deuze 2003).

In the last few years, studies on the representation of refugees and asylum seekers on digital media have provided data especially on North America and some European countries (e.g. Esses et al. 2013, Gabrielatos and Baker 2008, Ibrahim and Howarth 2016, Tudisca et al. 2017, Van Gorp 2005, Vieira 2016). Other recent research has also focused on print-based newspapers analysis about migrants (Berry et al. 2015, Binotto et al. 2016, Greussing and Boomgaarden 2017, Maneri 2011, Silveira 2016, Steimel 2010), including analysis within journalism (Barretta and Milazzo 2016, European Journalism Observatory 2015), which attests to the attention paid by journalists themselves to the way in which such a subject is being dealt with.

The aim of this paper is to understand and analyze the image of refugees represented by the online versions of two Greek newspapers, I Kathimerini and I Efimerida ton Syntakton. Given that the issue of immigration is not only built up by the accumulation of long-term news, but also by individual key events within a more intense public comparison, this paper does not refer to a long-term analysis as other recent studies have done (e.g. Barretta and Milazzo 2016, Berry et al. 2015, Greussing and Boomgaarden 2017), but to media coverage of one of the most significant events in the crisis of the refugees and asylum seekers ${ }^{1}$ in Greece and Europe during 2016, that is the evacuation of the Idomeni refugee camp, on 24 May 2016.

With respect to the selection of the two online newspapers, the main criteria were quantitative, namely, broad dissemination; and qualitative, namely, political orientation. Both newspapers have high circulation in the national context, both in printed and online versions, and may be considered opinion leaders (Boukala and Dimitrakopoulou 2017: 7, Triandafyllidou 2009: 39). As far as political orientation

\footnotetext{
${ }^{1}$ According to the 1951 Refugee Convention, as amended by the 1967 Protocol, a refugee is a person who "owing to a well-founded fear of being persecuted for reasons of race, religion, nationality, membership of a particular social group or political opinion, is outside the country of his nationality and is unable or, owing to such fear, is unwilling to avail himself of the protection of that country; or who, not having a nationality and being outside the country of his former habitual residence as a result of such events, is unable or, owing to such fear, is unwilling to return to it" (UNHCR 2010). States are under international obligation to consider claims for asylum and not to immediately return asylum seekers to the countries they have fled from. The refugee convention states that they must be given access to fair and efficient asylum procedures and measures to ensure they live in dignity and safety while their claims are processed. As regards the term "migrant", a uniform legal definition does not exist at the international level. However, "migration" is often understood to imply a voluntary process, for example, someone who crosses a border in search of better economic opportunities. Unlike refugees who cannot safely return home, migrants can return home if they wish. This distinction is important for governments, since countries handle migrants under their own immigration laws and processes. In this paper I use the term "refugees", "asylum seekers", and "migrants" at the same time since people who lived in Idomeni camp included mainly refugees escaping from Syria's civil war but also migrants from Afghanistan, Pakistan and other Middle Eastern countries who moved because of a direct threat/persecution, or to improve their lives finding work or reuniting with family.
} 
is concerned, I Kathimerini is a moderate and center-right newspaper, while $I$ Efimerida ton Syntakton is of the left orientation. Thus, this choice reflects the major trends and political orientation in Greece from different ideological backgrounds. Another criterion was that the newspapers had to be equipped with a freely available online archive. The search was done using a set of keywords

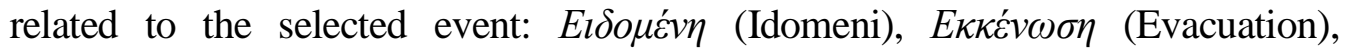

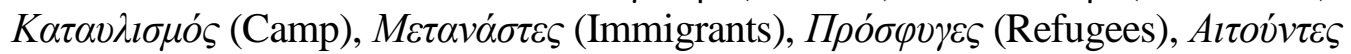

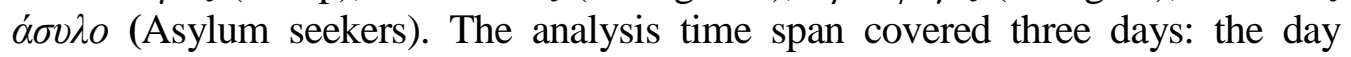
before, the day of the event, and the day after.

In the analysis of the two Greek online newspapers, the Multimodal Critical Discourse Analysis was used (e.g. Jones 2012, Machin and Mayr 2012, Royce and Bowcher 2007, Silveira 2016). Born as an extension of Critical Discourse Analysis, this approach recognizes the correlated importance of visual and textual modes in the discourse analysis. Indeed, it has allowed examining every form of communication in the social construction process, from written language to (audio) visual communication. According to Silveira, the textual and iconographical/ iconological analysis includes "actor and viewer, representation of different participants, representation of agency and action, and the 'grammar' of colour and visual design" (2016: 2). Using Machin and Mayr's words, this type of analysis allows exploring "the way that individual elements in images, such as objects and settings are able to signify discourses in ways that might not be obvious at an initial viewing" (2012: 31$)$.

In order to collect all data, analytical inquiry forms were used. During the preliminary stage to forms processing, documentary units have been defined, taking into account the richness of multimedia components, such as photo galleries, live articles, and videos. As a result, three different documentary units text, image and video that may be present in different combinations within a single article on the web - have been chosen, developing an inquiry form for each of them. The inquiry forms were designed to explore, in relation to the key-event of the evacuation of the Idomeni refugee camp, the following aspects and questions:

a. What were the main macro themes of the key-event? In the inquiry forms, the articles have been grouped according to the following macro themes: "Reception management", both at European level (e.g. refugee camp management, resettlement and relocation of refugees, European cooperation and missions, causes and solutions to the refugee crisis), and at national level (e.g. local management capacity, new legislation to regulate immigration, internal political conflict, governmental and institutional interventions); "Migrants' journey" (e.g. travel, border crossing, staying in the refugee camp); "Security and conflict" (e.g. threat to public security, threat to culture, identity and religion, social and economic costs, local protests against migrants, incidents/clashes among migrants, incidents/clashes between migrants and police, protests by migrants, racism and discrimination, anti-Islam fear rhetoric, health risk and spread of infectious diseases); "Integration" (e.g. social and cultural integration, recognition of refugee status/humanitarian protection, 
naturalization and acquisition of citizenship, family reunification, social services and welfare system, access to and use of health services, immigrant success stories, demonstrations in support of immigrants). In addition, values to immigrants have been examined, by recording the attitude - positive, negative, or neutral - toward immigrants/immigration in headlines and texts, meaning attitude as "the general orientation towards the object of social representation" (Moscovici 1988). Finally, the explicit or implicit perspectives underlying the text - "moral acceptance" or "problem" - have been analyzed.

b. What actors (e.g. political institutions, journalists, migrants and citizens, law enforcement agencies, NGOs, research bodies) have been mainly involved in news coverage of this particular event? What sources and authors of images and videos have been used, given that the sources are a key component in the construction of discursive frames (Berry et al. 2015, Binotto et al. 2016)?

c. Imagery related to the representation of migrants, by observing the use of lexical indices in the text - as rhetorical figures, having an important role in the construction of discursive frames, as shown by other studies on paper-based newspapers (Barisione 2009, Bruno 2014, Esses et al. 2013) and the subjects most represented in the images in terms of people, places, objects, and finally the presence of symbols. In particular - with respect to the composition of images of migrants - contexts, moods, space given to the individual or group of individuals were taken into consideration. In the latter case, it was useful also to consider the frame in which migrants were eventually represented as an anonymous de-humanized group, which is often included in the literature on media coverage of refugees and asylum seekers (Esses et al. 2013). More importantly, these elements were also related to gender and age in order to detect the presence of stereotyped representations.

d. What actions and emotions do news articles trigger in the readers? This occurred by observing the relationship between the type and the style of the text, and by analyzing the presence of the topics of suffering in the images. Regarding the first case, the style of the text has been classified in four categories: "informative" (neutral style characterized by describing notions and illustrating concepts); "persuasive" (style characterized by assertive messages, opinions, and sometimes moralistic tones); "propositive" (style in which solutions are proposed); "participative" (style that encourages the reader's involvement). As for the topics of suffering, the images have been classified according to the three topics proposed by the sociologist Luc Boltanski in the early 1990s (1993) to describe how an image can produce moods and actions: the topic of denunciation, where the image induces the spectator to be indignant against a "persecutor"; the topic of sentiment, where the image induces the spectator to sympathize with a "benefactor" to whom the unfortunate would be grateful; the aesthetic topic, where the spectator views suffering as "sublime". Two new 
topics were also included: neutral topic and topic of joy, for images not related to suffering.

\section{Humanitarian Crisis and Idomeni Refugee Camp}

As for refugees and asylum seekers, the international framework has been constantly changing and has its roots in the persistence (for decades) of conflict situations in Afghanistan and Somalia; in the civil war in Syria, where half of the population has been uprooted by the country; in new conflicts exploded in Ukraine, Yemen, the African Republic, and Burundi. In 2016 the main migratory routes to the EU were four: Central Mediterranean route, which originated from Northern Africa, particularly from Libya, travelled by people fleeing from subSaharan Africa, the Horn of Africa and the Middle East; Eastern Mediterranean route, ranging from Turkey to Greece, Bulgaria and Cyprus; Western Mediterranean route, from Northern Africa to Spain; Balkan route, used by migrants to enter Europe from the countries of ex-Yugoslavia (Cagiano De Azevedo and Paparusso 2016: 63) ${ }^{2}$.

According to UNHCR data (2016a), in 2015 Greece witnessed a massive increase in the number of sea arrivals, via the Eastern Mediterranean route: 385.069 people, from the beginning of the year to the end of September. The increase began in August, with 107.843 arrivals, and peaked in October, with the highest number of arrivals recorded during the year (211.663). In 2016 there was a sharp decline: from 67.415 arrivals in January to just over 2.000 in March, bringing the total to 165.750 units; a $57 \%$ drop compared to 385.069 arrivals recorded in Greece in the first nine months of 2015. The drastic reduction continued in the following months, especially after the agreement between the EU and Turkey to manage the arrival of migrants, by which, from 20 March 2016, all new irregular migrants from Turkey to the Greek Islands will be returned to Turkey. Undoubtedly, this agreement changed the map of the Mediterranean crossings, by creating an insurmountable "wall" on the Aegean sea. According to EUROSTAT data (2016), in 2016 Greece was one of the first EU countries for number of first time applicants with 49.875 first time asylum seekers (4\% of all first time applicants in the EU Member States), after Germany, Italy and France, recording a change of $+339 \%$ compared to 2015 . Compared with the population of each Member State, Greece registered the highest number of first time applicants (4.625 first time applicants per million inhabitants) after Germany, and followed by Austria, Malta, Luxembourg, and Cyprus. In 2016 the main nationalities were: Syria, 53\%; Iraq, 10\%; Pakistan, 9\%.

Since 2014, refugees escaping from Syria's civil war - but also from

\footnotetext{
${ }^{2}$ It should be noted that the Balkan route is a more recent development whilst the Central Mediterranean route is a longer-term route. The Balkan route was officially closed in March 2016 when the EU and Turkey struck a deal after thousands used the route to get from Greece through the Balkan countries and on to Western Europe. However, a growing number of migrants and refugees are using the new Balkan route through Albania, Montenegro, Bosnia and partly Serbia to reach the EU raising concerns of a humanitarian and security crisis.
} 
Afghanistan, Pakistan and other Middle Eastern countries - began to move towards Idomeni, a small village in Central Macedonia, in order to cross the Greek border with the Former Yugoslav Republic of Macedonia (FYROM). FYROM, along with Serbia, was one of the countries belonging to the "Balkan route" that migrants crossed with a view to reaching Germany and the countries of Northern Europe. This route was favored by migrants because it crossed countries that were not part of the Schengen area and therefore, in the event of an arrest by the Serbian authorities, the refugees were sent to the Croatian or Hungarian borders (which were closer to the desired destination countries), rather than to Greece, which was much further south. In 2015, FYROM decided to close its southern borders with the aim of preventing migrants from entering, except for a few hundred Syrians. This decision was taken following similar border-control measures by the Serbian government. This political initiative caused a humanitarian crisis in Greece, and Idomeni became a large refugee camp that increasingly housed people wishing to cross the border towards the north. In March 2016 the migration crisis reached an unsustainable situation: the refugee camp had a number of migrants equivalent to ten times the maximum capacity of accommodation. About 10.000-12.000 people, of which around 4.000 were children, lived in disastrous conditions in an informal settlement near the border, around a railway station (UNHCR 2016b). Most were families, many of them with small children. Hygiene condition was one of the major worries because of the negative impact it could have on people's health. Immigrants burned plastic and rubbish to keep warm. This resulted in intervention measures by EU Member States, UNHCR and humanitarian organizations (such as Doctors Without Borders) aimed at improving reception capacities, by providing family tents for up to 2.400 people and portable latrine services, and by collecting waste from the camp. On 24 May 2016, the Hellenic police began the evacuation of the Idomeni refugee camp. Police operations began at dawn and were conducted without the use of force by more than a thousand Greek police officers. The evacuation, which lasted about a week, was initially focused on small tents scattered in the informal settlement and then on those around the railway station. Refugees were transferred by bus to reception facilities in the north of the country by means of EU financial support. Only by accepting such a transfer could the refugees obtain a one-month extension of the temporary residence permit. However, some new refugee sites were far below minimal humanitarian standards. Some refugees and migrants were moved to abandoned warehouses and factories, where tents were set up very close to each other. The air circulation was poor, and the availability of food, water, sanitation, showers, and electricity was inadequate. Refugees transferred from Idomeni received little information on the conditions in the new settlements and on the expected length of their stay in these places. UNHCR reported spontaneous arrivals of refugee families, some of whom left Idomeni on foot, at several settlements, which were already overcrowded. The difficult conditions in these sites aggravated the already high level of suffering among refugee families, fueling tensions within refugee population and complicating efforts to provide necessary assistance and protection. 


\section{Results: Textual and Visual Analysis}

The analysis has led to the identification of 71 total documentary units: 19 texts ( 9 for I Kathimerini and 10 for I Efimerida ton Syntakton), 48 images (19 for I Kathimerini and 29 for I Efimerida ton Syntakton), and 4 videos (1 for I Kathimerini and 3 for I Efimerida ton Syntakton).

\section{A. Textual Analysis}

With regard to the general characteristics of the texts, there is a certain balance between signed and unsigned articles, both with 9 units, while only 1 article was taken by a news agency (ANA-MPA, Athens News Agency Macedonian Press Agency). Over half (10 articles) appeared on the web the day after the key-event, 7 articles were written the same day and 2 the day before. The length, measured as a number of words, varies considerably. Each newspaper has published articles of varying length, with an average number of words per article of 519 units. This result can be read as an indicator of the level of depth and relevance given to the event, especially by I Efimerida ton Syntakton, which has a maximum length of 1.735 words for one article.

The prevalent macro theme is "Reception management" (19 cases), followed by "Migrants' journey" (12 cases), "Security and conflict" (5 cases) and "Integration" (4 cases). I Kathimerini emphasizes "Security and conflict", more than I Efimerida ton Syntakton, referring to problems of public order and protests by local authorities against settling immigrants from the camp into new reception facilities. The main macro theme "Reception management" develops on two levels: the supranational (European) and the local levels that intersects and overlaps with reality and communication. The Greek newspapers tell of a Europe divided internally and unable to provide common and effective responses to the migration crisis. At the same time, the newspapers take into account the complexity of the issue and the central role of the EU. In fact, the refugee crisis is a political issue before it is social. And it is politics that is the mainstay of the media narrative of the migratory phenomenon. In addition to the fences of the Idomeni refugee camp, there is also discussion on political issues and different perspectives on reception. It is a communication of political and institutional confrontation, at European, national and even local levels, in the background of images and stories of the refugee camp. As Marcello Maneri suggests, it is a political confrontation around this news that facilitates their stay in the foreground of national information: "Without political legitimacy and diagnosis and solutions, media emergencies would be extinguished pretty quickly" (Maneri 2009: 71).

Regarding the sources used in the texts, there is a predominance of official and institutional information: national political institutions and journalists/media, followed by other sources such as European political institutions, NGOs and law enforcement/military personnel. Undoubtedly, using institutional sources gives information a semblance of truthfulness and validity, by reinforcing its credibility (Binotto et al. 2016: 86). The choice of institutional sources is based on their direct access to the "facts", their reliability, and their ability to provide the media with 
continuous inputs presented in an easily recoverable format. Despite the huge media attention to the key-event of the Idomeni camp clearance, migrant voices are largely absent from narratives. Although they are the real protagonists, they appear instead as the object of communication and an indistinct mass. This practice of describing an event without using migrants' voices, replaced here by those of politicians, journalists and law enforcement, emphasizes the focus on debate by subverting it to the subjective experience of migrating. As in other studies on the refugee crisis (Barretta and Milazzo 2016), there is no detail on the origin and life before the migrants' experience, thus individuality is sacrificed to the tale of the mass phenomenon. Migrants' voices, therefore, do not appear in the construction of the narrative of the evacuation, even in the presence of polyphony. Even nationalities are not mentioned, reiterating the first fundamental negation of foreigners: the possibility of calling them with their name and identifying them not only as immigrants but also as emigrants. Thus, linguistic censorship is one of the most common forms of making people invisible, and individuals become part of an identical migration flow. On the level of discursive practices, it corresponds to the social invisibility of certain categories of human beings treated as "nonpersons" (Dal Lago 1999). By "neutralizing" information, thousands of people are eliminated or removed as if they were a purely theoretical problem. Moreover, the results show that, on both newspapers, we are almost always in the presence of a monodimensionality, as there is no reflection on the macro-phenomena and structural causes of migratory phenomena such as the conflict in Syria, international crises and economic globalization. This de-humanization of refugees and asylum seekers may be useful to justify their status quo, reinforcing the boundaries between in-group and out-group, justifying the control of the status of immigrants and the protection of available resources (Esses et al. 2013, Haslam 2006, Leyens et al. 2000). It should be noted, however, that the choice of not using migrants as a source can be determined by the difficulty of accessibility: reluctance of migrants to speak, fear of repression, and fear for the outcome of the asylum application, linguistic barriers and so on. In our case, for example, media coverage within the refugee camp during the evacuation was only granted to some media and journalists (Hellenic Broadcasting Corporation and ANA-MPA) and this may have represented an obstacle to approaching migrants.

Another interesting aspect is definitely a significant use of numbers and figures in the newspapers' text. This deals with immigrants' presence in the camp, and the relocation of people to other reception centers after the evacuation, and the police officers who took part in the camp clearance operation. As a result, the description in numbers leads to a representation of refugees as an undifferentiated mass rather than as individual human beings, and may lead the reader to feel less empathy for the migrants themselves.

As for the type of article, for both newspapers, the prevalent is the news section (16 units), followed by only 2 editorials and 1 press review. For both newspapers, the most frequent style is the informative one (16 cases), better suited to the news section, while the persuasive ( 7 cases) and the participative styles (1 case) are less frequent. No texts show the propositive style. The newspapers include mostly news reports, at the expense of deepening through journalistic 
inquiry. The main attitude towards immigrants and immigration in headlines and texts is neutral for both newspapers (15 cases, while positive and negative are, respectively, 3 and 1 case). It is important to note that, in considering the attitude, it not only referred to the author of the article, but also to quotes of sources and actors mentioned in the articles. These results show how both newspapers reveal a tendency toward homogeneity and privilege and aseptic and impersonal language. Greek newspapers use an institutional approach characterized by factual orientation to the news and criteria of completeness and impartiality that are typical of the generalist newspapers with an institutional approach. What Sorrentino (2006: 12) calls "temperate differentiation", namely when a newspaper tries to distinguish its approach and editorial line, rarely appears, with the only exception of I Kathimerini when giving more emphasis to the macro theme "Security and conflict". Both newspapers often use the same style of exposition, narrative and language, and provide the same explanations. In many articles no judgment is given, positive or negative. Both newspapers produce continuous formats marked by repetition, conformity and predictability. We are faced with what Michel Foucault calls "dispositive" (1975), with a set of highly repetitive and recognizable content: a dispositive connecting collective feelings and media representation with a range of public policies and institutional practices geared to disciplining and controlling. Despite the different political orientation, they appear to be "twin newspapers" designed more to create a homogenization of views and explanations than to provide a plurality of opinions. In this sense, the tendency of information to confirm pre-existing social representations (Sorrentino 2002: 24), and to reiterate stereotypes (Caniglia 2009) is dominant. The information machine is increasingly less able to grasp the novelties, intent on preserving and reiterating its routines (Tuchman 1978). The use of similar formulations and metaphors can only accentuate the feeling of being faced with a film always locked on the same frame. An example are the interchangeable headlines (for example, To $\sigma \chi \varepsilon \dot{\delta} \delta o$

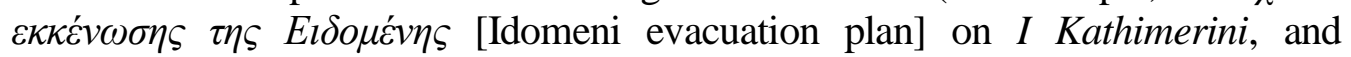

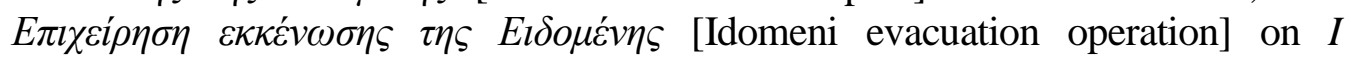
Efimerida ton Syntakton), not only because referring to similar facts, but also because of a similar way of providing explanations, describing a pernicious danger, or offering solutions. Despite the otherness of refugees from the nation is implicitly introduced by terms defining a boundary line, such as $\mu \pi \alpha i v o v v \sigma \tau \eta v$

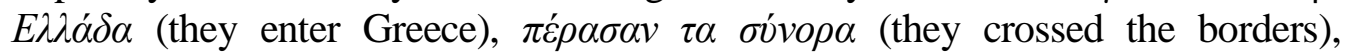
$\varepsilon \delta \omega^{\prime} / \varepsilon \kappa \varepsilon i$ (here/there), $\varepsilon \pi \imath \kappa \rho \alpha ́ \tau \varepsilon l \alpha \mu \alpha \varsigma$ (our territory), it should be noted that Greek newspapers do not give in to the temptation, in sensationalist terms and tones, to spectacularize the key-event in order to increase their readers numerically. This may be observed in the absence of terms such as $\lambda \alpha \theta \rho o \mu \varepsilon \tau \alpha v \alpha \dot{\sigma} \sigma \eta \varsigma$ (illegal migrant), $\pi \alpha \rho \alpha ́ v o \mu o \varsigma$ (irregular) and $\xi_{\varepsilon}^{\prime} v o \varsigma$ (foreigner), all replaced by $\pi \rho o ́ \sigma \varphi v \gamma \alpha \varsigma$ (refugee). However, it is also true that this narrative neutrality can be incorporated into a standardization framework on immigration issue. In fact, beyond ideological and political differences, the refugee crisis is increasingly becoming a "commonplace" of our daily information, as a sign of "normality". And it is true that, in online newsmaking process, information systems are attuned to the media needs of cost-effectiveness and speed. Thus, these needs regulate the production of 
news under the constant pressure of instantaneous communication resorting to typing or stereotyping, in order to reduce the time of both news production and news reception. The need for instantaneous communication leads, according to Sbriscia (2001), information systems to resort to commonplace favoring discourse reproduction of beliefs.

On digital media, the issue of immigration is addressed and outlined also, and above all, through specific rhetorical figures within the discursive frames portraying manifest and latent content, in order to deal with the subject more incisively. As interpretive principles, narrative frames are manifested in discourse through symbolic dispositives like metaphors, examples, visual images and slogans, important for organizing information concerning broader cultural ideas. Both Greek newspapers do not make excessive use of rhetorical figures and when they appear they are mostly in the headlines of the articles. In most cases, these are

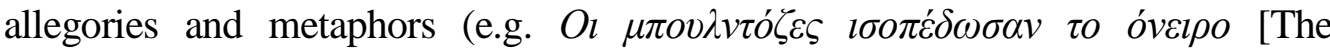

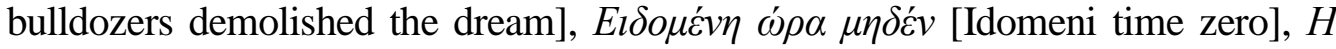
$\mu \iota \kappa \rho \eta$ " $\pi \delta ́ \lambda \eta " ~ \tau \eta \varsigma ~ E l \delta o \mu \varepsilon ́ v \eta \varsigma$ [The small "city" of Idomeni]). In the text, I Kathimerini also makes sporadic use of the rhetorical figure of irony to express dissent to the national policy of the Greek government, claiming the ideological/

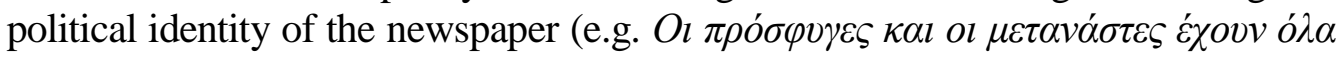

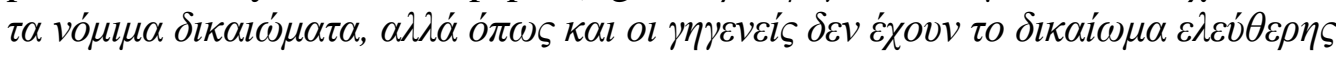

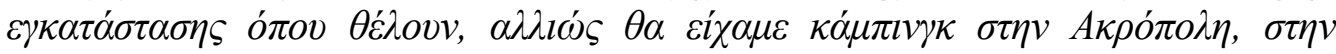

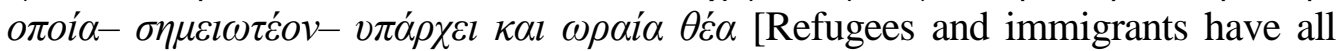
legal rights, but, as the locals, they do not have the freedom to settle where they want, otherwise we would camp at the Acropolis where there is also a nice view]).

Finally, with regard to the implicit or explicit perspective, the results of this analysis show a perfect balance. Both newspapers have, to the same extent, a perspective on the migratory phenomenon between "problem" and "moral acceptance". This contrasts with the findings of a previous study on media coverage of the migrant crisis on the same two paper-based newspapers (Papadopoulou 2015), where a more humanitarian approach was emphasized by $I$ Efimerida ton Syntakton compared to I Kathimerini. Indeed, the latter focused its articles on the negative impact of the migration phenomenon on Greek society, on health risks and the spread of infectious epidemics, and on the frustration of local communities. It is important to note that also here, we refer not only to the author of the article but also to very frequent quotes of sources and actors mentioned in the articles. This means that institutional actors "replace" authors, especially when Greek newspapers want to highlight immigration as a problem. We are faced with the effect of a discursive strategy in which many quotes are selected in order to provide the reader with a comfortable version of what happened.

As in other studies on the refugee crisis (e.g. Gemi et al. 2013; Horsti 2008, Klocker and Dunn 2003, Van Gorp 2005), the media coverage of the analyzed Greek newspapers polarizes around two representative frames: a) alarm/ emergency frame, that is fairly negative towards the presence of refugees and asylum seekers, and b) pietism/victimization frame, characterized by a compassionate and paternalistic attitude towards immigrants.

As far as the alarm/emergency frame is concerned, Greek newspapers 
represent immigration as a problem to be solved and immigrants appear almost always as passive victims. Immigration is a problem in itself, first and foremost as a social problem, not so much in terms of invasion but rather in relation to difficulties in managing refugee crisis and public order. This kind of narration also confirms issues of public securitization by urging European and national politicians to "do something". Despite the neutrality of narrative, it allows to objectify fear, build opinions, promote particular perspectives on public security, legitimize actors on the scene of public debate, and support restrictive access policies. The language is defined in terms of a particular set of features, from the obsessive repetition of the emergency label and stereotypes to a very broad spectrum of crisis moments, such as the economic crisis that Greece has been going through over recent years. The emergency is no longer just the wave of migrants, but the crisis of an economic and social system. Moreover, it may be related also to the economization frame (Hier and Greenberg 2002, Quinsaat 2014), in terms of social and economic costs for Greek society. On the other hand, the pietism/victimization frame calls attention to moral acceptance and a humanitarian approach to asylum policy and to legal and moral obligations (Harrell-Bond 1999). However, the very concept of moral acceptance is not about action aimed at accommodating and helping people in difficulty. It is in terms of bureaucratic and practical organization to manage and settle people who illegally reside in the refugee camp, by describing a strongly critical and emergency situation. It is to be said that this frame is equally stereotyped in labels and representations, drawing largely from collections of stereotypical images on the otherness, that deal with paternalism. The approach of the alarm/emergency frame (perspective on immigration as a "problem") as opposed to the speculative pietism/victimization frame (perspective on immigration as "moral acceptance") demonstrates the effectiveness of this conceptual couple. It is a bipolar and agonistic perspective, perfect for the media gaze.

\section{B. Visual Analysis}

In this analysis, 48 photographs and 4 videos have been analyzed both in relation to articles text and as independent content, to testify their relevance in online information, not just as complementary elements to texts. Regarding the source of the photographs, 29 photos were made by an author (mostly press agencies), while in 19 photos the source does not appear. In this respect, an interesting point deals with the fact that the photographs in which the author does not appear are all belonging to I Kathimerini. In reference to the videos, the only source is the Hellenic police.

With respect to the composition of images of migrants, age, gender, contexts, moods, space given to the individual or group of individuals are taken into consideration, also in order to detected the presence of stereotyped representations. Furthermore, the images have been classified according to the topics proposed by Luc Boltanski (1993) which are extremely useful to understand an iconographical language including people, places, and symbols. Indeed, an iconographical language is able to spread knowledge more effectively than almost any other 
means of communication, because it gives the illusion of being universal, by not (apparently) presenting language restrictions. Photography and video are used to witness or give emotions, but above all they point to the reality: they serve to document, illustrate and support a story (Altheide 2000). The role of media images in the process of "social construction of reality" (Berger and Luckmann 1966) and the negotiation (Hall 1980) of the meanings and opinions on the world by the public is evident. Indeed, the public, interacting with the media, builds social representations of reality (Farr and Moscovici 1984) or social representations of the otherness, by redefining the boundaries of acquired knowledge through a specific context of representation (Meyers 2002).

While in the articles' texts the two Greek newspapers put lives of the camp's refugees in the background, the images instead make them come out strongly, while showing their anxieties and their dreams. Their silenced words in almost all of the texts burst into the semantics of images representing conflictual dialectics. The two newspapers show images with a strong emotional impact. In particular, the articles frame the key-event within an interpretive framework, relying on an iconography aimed at carrying out a function of denunciation of refugees' treatment.

In all analyzed videos, the focus is the clearance operation of the Idomeni refugee camp. These are videos (without audio) by the Hellenic police, in which the evacuation of the camp is taken from above, aboard a helicopter or through a drone's eye. Police operations began at dawn and were initially focused on small tents scattered in the informal settlement and then on those around the railway station. Refugees were transferred by bus to reception facilities in the north of the country. Only by accepting such a transfer could the refugees obtain a one-month extension of the temporary residence permit. The interesting aspect of these videos is the low presence of the individual dimension and the high presence of an undifferentiated mass. Neither age nor genders are recognizable. As suggested by other studies (Bleiker et al. 2013; Silveira 2016), this visual framing, and in particular the absence of video images that depict individual asylum seekers with recognizable facial features, could associate refugees with threats to sovereignty and security. In addition, clustering refugees into one single undifferentiated mass deprives them of their biographical specificity as historical beings (Nyers 1999), while defining them in terms of their corporeal vulnerability alone degrades them to the status of "sub-citizens" - their physical destitution lacks the legitimacy to articulate political will or rational argument (Hyndman 2000).

In certain respects, the situation concerning the photographic representation is similar to the video representation. A similarity is a low presence of the individual dimension: in 33 photos, migrants are represented in groups, compared to 15 cases in which they appear individually. Images show adult and children (17 cases), only adults (17 cases), only children ( 8 cases), and in 6 photos age cannot be identified. However, I Kathimerini, unlike I Efimerida ton Syntakton, tends to represent, in half of the cases, only adult migrants. Regarding gender, in 16 photos, there is a mixed composition (male and female), while in 18 cases migrants are male, compared to a low percentage of females ( 8 cases). In 6 images, gender cannot be identified. These data seem to deny a trend in the media to associate refugees with 
the image of women and children (Baines 2004, Johnson 2011, Rajaram 2002, Silveira 2016), recognizing that the analysis of iconographical/iconological components is of utmost interest in understanding stereotyped representations of refugees in the social construction process of reality by the media. In Foucault's view, such a discourse on stereotyping can be read in a biopolitical way, meaning biopolitics as the symbolic arena in which the power of managing and representing the body is expressed. That is, a field of forces where the body becomes "social" and "cultural" in a collective imagery where the media insist on vulnerability, fragility, and the need for protection emanating from the image of a mother with her children.

Photographs can contribute to how viewers imagine refugees with implicit and explicit aims of triggering compassion, fear or empathy (Haaken and O'Neill 2014, Johnson 2011), since visual depictions of refugee situations are assumed to convey a certain reality, an assumption that such things exist (Szörényi 2006). Immigrants' moods emerging from photos in this analysis are, in over half of total cases, of "seriousness" (26 cases), followed by "hope" (12 cases) and "fear" (5 cases), mainly expressed by the gaze as well as posture. From the analysis of the topics, the one of denunciation is especially noticeable (30 cases), particularly when children are depicted, followed by the aesthetic topic (10 cases). The topic of sentiment and the neutral topic are very less frequent, while the topic of joy is completely absent. They are almost all images depicting the evacuation of the Idomeni refugee camp: actions and interventions of law enforcement officers, migrants leaving their own tents and collecting/packing their stuff in poor suitcases and garbage bags, protest signs calling for human rights; other images illustrate long lines of migrants leaving the camp walking to the buses that will take them to other reception centers, and tired and serious faces of migrants hoping for a better life. They are images belonging to the topic of denunciation, which appeal to a sense of justice and generate indignation. What characterizes this topic is a search for responsibility. Attention is directed to a culprit and not to a victim. Thus, anger leading to the denunciation is moved by "sympathizing" (in the sense of suffering together, sharing a particular emotion) with the resentment of the victim (migrant) against the persecutor (police, government, EU). As regards the aesthetic topic, images represent suffering as "sublime" (for example, fine art photographs). These images are limited to representing the problem without indulging in pity, and are intended for an interiorized and individual perception, without any ambition to arouse concrete effects in terms of collective action. In reference to two Greek newspapers, examples are migrants posing and looking at the photographer's camera, as in a hand-painted family portrait; or static and serious faces of two migrants in front of the dilapidated railway station of Idomeni. The fundamental feature of the aesthetic topic is the refusal of feeling, "doing nothing", by looking at what is being seen, and avoiding too many emotions and feelings. They are images where a sublimation of the gaze transforms an object into a fine piece of art without any moralization.

The angle of an image is of particular importance for iconographical analysis. In some photos refugees are shown from behind, making it harder for the viewer to identify with them. In this sense, they represent the unknown and anonymity. As 
Silveira suggests:

"The distance from the camera, and the fact that the subjects have their backs turned as if they do not know they are being watched, aligns the image with the aesthetic of security surveillance footage. As the employment of security cameras is associated with keeping order, or in other words, to help prevent and prove criminal behaviour, this brings about associations with illegality" (2016: 9).

On the contrary, for other photos, even when migrants have been represented as large groups,

The faces of portrayed people are clearly shown. This makes it easier for the viewer to identify with them. When subjects are positioned in the center of the frame and the camera lens is focused at a short range, for the viewer it is more likely to capture the emotions of migrants. In this case, they are described also as "human beings" who arouse pity. They are images that produce suffering and compassion rather than xenophobic reactions. The Idomeni camp refugees do not appear to be criminals. They may represent, if anything, a threat to European security. Because they emphasize the global instability of our time. The image is no longer a neutral historical document, but a mosaic of faces that meets the viewer's eye. Biographies of migrants, omitted from the texts of the articles, resurface in these portraits making their existence visible. They are faces on the scene, crossing the symbolic threshold of invisibility, to be placed on a "stage" in which they are real actors, through a process of re-humanization, whereby migrants cease to be numbers and become human beings again. At the same time, other images imply an objectification of refugees when they portray them in moments of intimacy and privacy, in front of their tents or gathered around a bonfire, especially during the days before the evacuation. Their personal spaces are violated and they become objects of an intrusive gaze creating an aesthetic of violence, as well as the understanding of the refugee body as a non-sacred entity. Such a discourse can be placed into a broader debate that deals with what Ortner (2016: 47) calls "dark anthropology," that is, "anthropology that focuses on the harsh dimensions of social life (power, domination, inequality, and oppression)" and can also be extended to the methods and ethical protocols of journalistic practice in these situations. Indeed, these violation and objectification of refugees as "suffering subjects" (Robbins 2013) through an intrusive gaze of the photographer's camera lead us to the question posed by Kelly (2013: 213): "at what point does ethnography of suffering turn into a voyeuristic quasipornography?"

The topic of denunciation takes place in the presence of strong recurring symbols that characterize the images: barbed wire and chain-link fence encircling the camp, protest signs, bulldozers, and garbage bags used as luggage and wheelchairs for the disabled. The chain-link fence limits migrants to a physical space until, presumably, someone with a higher authority allows them to get out. The visual representation of the barbed wire recalls internment camp memory and the tragedy of people deported and expelled by nationalistic policies and regimes. 
This idea of imprisonment may be related to both the perceived "illegality" of migrants entering Europe, and their victimhood, since they are detained within a global regime characterized by humanitarian practices and particularly restrictive control measures. "Bulldozers demolishing the dream" do not only act in a pragmatic universe but are also actors of a show destined for representation. The image of the camp's demolition by the bulldozers gives a sense of a physical, symbolic, political and social exclusion. The bulldozers' action is not only a historical evidence of such an event, but also the profoundly symbolic extract of the government's actions. Tents, clothes drying in the sun, food, blankets, garbage bags used as luggage, and protest signs become significant as they are inhabited, used, consumed, as inanimate objects but also as symbolic extensions of the lives they belonged to. In this sense, the lives of immigrants become increasingly tangible through these objects, showing to the viewer how their passive resistance becomes voice.

Both in photographic and video representations of the demolition of Idomeni camp, although we do not perceive tension, conflict is semantically emphasized by police performance and suggests a coercive attitude by public security forces. The images and their captions describe the conflict-negotiation process that opposes migrants to law enforcement. It is an iconographical language connecting the Schengen Fortress ideology to an immediate and direct image of the "human surplus" that legitimates the existence of an internment camp (Rahola 2003). The crumbling Idomeni camp represents a non-place of humanity in excess where, using Sayad's expression (1999), the refugee is atopos and exists only by default in the sending community and by excess in the receiving society. Refugees, stripped of any sense of belonging, must disappear from sight and must fade from memory, and the physical traces of their presence must be dispersed quickly. We are in the presence of an ideological and operational device for which migrants are subjects to expulsion and protection, to settle in a marginal separated and monitored area. Their transfer, albeit temporary, to other reception centers seems to be an "exemplum" of this mechanism of exclusion, and represent the only possible re-territorialization within a political and social system in crisis. They are all images of a European Union that has reduced citizenship to an exclusive paradigm, a tool to select temporary (sovra) national belonging, in addition to the protection afforded by law. Another interesting point to note is the paradox inherent in the narration of the evacuation operation of the refugee camp: what remains "clandestine" for police forces is perfectly identifiable for media observation. Immigration becomes visible when it is legally invisible. In fact, it is the police operation to transform a silent event into a media show, when, for example, authorities posted helicopter footage of the camp clearance on the Internet. The entire information apparatus brought to play confirms this metaphorical reading key, from the images portraying police officers restoring order in the name of legality, to the barbed wire symbolizing a border, a trench, to be protected. It is equally obvious that this metaphor not only recalls some specific illustrative choices, but also a recurring language that corresponds to many political-administrative solutions (Maneri 2009: 83-85). 


\section{Discussion and Conclusion}

Refugees are at the center of a conflict between international obligations and nation-states. In a world still politically based on nation-states, they have lost the protection of their country of origin but do not enjoy citizenship rights in the receiving country. Hanna Arendt's reflections (1951) on the link among national belonging, citizenship, and rights are reminiscent of the fact that the lack of citizenship, by national definition, makes refugees stateless persons. The issue of refugees is therefore probably the highest point of tension between the interests of national states and the protection of human rights. The absence of effective European policy solutions in these years contributes to maintaining a reduced protection regime for refugees, from suspended rights to subordinated inclusion. Media and political system work to build an image of public intervention to contain the emergency and to solve problems. They are political options and strategies through which media representations define an image of public action as well as a collective imagery.

The demolition of the Idomeni camp was a central theme not only for the Greek media, but also for the European ones. It was a spectacular media event through which the Greek authorities reaffirmed their control over the national space. Characterized by humanitarian practices and particularly restrictive control measures, the Idomeni camp, as well as all other camps where asylum seekers are held, has represented a "symbolic place of the social construction of the refugee" in contemporary times (Van Aken 2005: 7). As a primary policy measure for administering and controlling asylum migration, the camp is, first of all, a site characterized by humanitarian practices with techniques of power experienced by asylum seekers as acts of overwhelming violence. In the last decade, the system of camps as a political form of governing and controlling refugees and asylum seekers is increasingly being used in the various European states, while making the current historical moment "a time marked by the pervasive presence of the camps" (Rahola 2005: 69). Similarly, refugee camps are zones of exception outside national borders, administratively and legally separate from political space. Therefore, the Idomeni camp was not a historical anomaly. Rather, it is the symbol of a "new biopolitical nomos of the planet" (Agamben 2000: 45), through which fundamental human rights are suspended or denied (Frost 2013).

The anthropologist Michel Agier emphasizes that the global humanitarian system has adopted a principle that he calls "care, cure and control" that makes camps "police, food and medical devices", where refugees "are kept below minimum humanitarian standards and they are nourished within norms of mere survival" (2005: 50). These practices denote the control obsession that drives host countries to settle asylum seekers in camps rather than letting them disperse around the country. Therefore, camps, although defined as protection structures for asylum seekers, have the function of ensuring the safety of those outside (citizens) from the subjects (not citizens) living within them (Diken and Lausten 2006). More concretely, the camp, as a management and reception strategy for asylum migrations, has been in line with a depoliticization of the refugee figure and with recognition of forms of assistance, from time to time, by State agencies and 
international programs. The figure of the refugee/asylum seeker becomes increasingly "humanitarian", from a historical and political subjectivity to an object of "care and control". In other words, it is recognized as humanity in excess, needing to be rescued with categories related to aid and reception (Malkki 1996; Van Aken 2005). As Agier writes, although the camp solution should be "the exception", it actually becomes an "ordinary" political rule (Agier 2009: 35), and the agencies themselves, that should protect refugees and integrate them socially, lock them up in prison-like conditions.

By using the Multimodal Critical Discourse Analysis, this paper focuses on the visual and textual representation of refugees in the online version of two influential newspapers in Greece. The analysis examines the particularities and significance of news coverage of a particular and critical event. The detailed analysis of news texts and photos associated with this event informs the discussion and proposes a critical understanding of the narrow representational frames within which refugees are constructed in the media. The textual and visual analysis of the media coverage of the Idomeni camp evacuation has allowed to identify many elements related to the representation of migrants. The results show that the construction of the imagery of migrants and migration is based on a discursive/visual representation of migrants and components with strong symbolic values which have now become part of our imagery.

The first and main observation from this analysis is that, despite the different political orientation, both newspapers are very similar in their coverage, revealing a tendency to more a homogenization of views and explanations than to providing a plurality of opinions. Using an institutional and generalist approach based on monodimensional formats, they thus contribute to perpetuating a dispositive suitable for pre-existing social representations and stereotypes.

In line with other works on refugees and asylum seekers (Gemi et al. 2013, Horsti 2008, Klocker and Dunn 2003, Van Gorp 2005), in the text, both Greek newspapers focus on two representative frames, alarm/emergency frame and pietism/victimization frame, that are equally stereotyped in labels and representations. These frames revolve, in a particular way, around the macro theme of reception management that develops on the European and the local level through a political and institutional debate.

In the text, the online newspapers leave no space for the voices, origin and living condition of migrants. Even in the presence of polyphony, their life stories do not contribute to the construction of the narrative of the evacuation of the Idomeni refugee camp, and individuality is sacrificed to the tale of the mass phenomenon. Also the description in numbers plays an important role in representing refugees as an indistinct mass rather as individuals, making them socially invisible. Undoubtedly, in accordance with other literature findings (Esses et al. 2013, Haslam 2006, Leyens et al. 2000), this institutionalized practice of dehumanization constitutes an effective mean to justify the control of the status of immigrants, reinforcing the boundaries between in-group and out-group.

Another important point is that, unlike the articles' texts, both I Kathimerini and I Efimerida ton Syntakton show images making biographies of migrants visible. As we have seen, images often cross the symbolic threshold of invisibility, 
to be placed on a "stage" in which they are real actors, through a process of rehumanization, whereby migrants cease to be numbers and become human beings again. These images mainly belong to an iconography that recreate the singularity of suffering and is directed to a denunciation of refugees' treatment, whereby viewers are expected to take sides with the migrants and sympathize with them, above all when the faces of portrayed people are clearly shown.

The above results indicate that in the media representation of refugees and asylum seekers, cultural clichés, on which discursive and iconographical choices are based, tend to re-emerge systematically in a vicious circle. The neutral and homogeneous language of Greek newspapers, the two frames representing problem/alarm/emergency and moral acceptance/pietism/victimization, the absence of migrant voices from narratives, the images of the Idomeni refugee camp, seem to confirm this vicious circle as a consequence of the framework of relations among actors, mediators, and representations: a field of forces dominated by the paradoxically stabilizing stereotype persistence. Most importantly, the representation of refugees in the frame of victimization, along with ritual manifestations of compassion on the media and the European political scene, might have a counterproductive effect on refugees. Because involuntarily - and falsely - they reduce the status of refugees to a state of inactivity and passivity. But having said that, stories of suffering are not a fiction but a reality for those millions of people who have fled wars and tragic situations, and deserve to be told. However, in continuing to insist on "essentialist" refugee-victim narratives, this communication is paradoxically an obstacle to the language of empowerment of humanitarian agencies. In addition, in line with Kapur's argumentation (2002), attitudes and practices such as paternalism or overprotectiveness may affect European political decisions regulating the resettlement of refugees, so as to deprive them of their agency and obstruct their empowerment. The short-term benefits of the proliferation of such images with their metaphorical power must therefore be critically evaluated, by reflecting the potentially negative repercussions on public beliefs and attitudes towards (forced) migrants. The almost ritualized images of "victimhood" of refugees serve more to demonstrate the EU's compassion and self-assertion than to stimulate a significant change in public attitudes or politics. People who have lost homes, jobs, relatives, their daily lives, must be taken seriously, not as people reduced completely to "naked life" as supported by the philosopher Giorgio Agamben (1998) - but as active members within a global political community, in order to avoid the perpetuation of an essentialist discourse. However, the fact that, unlike previous studies by other scholars on visual representation of refugees (Baines 2004, Johnson 2011, Rajaram 2002, Silveira 2016), images of adult and male migrants were prevalent in this online newspapers analysis could suggest a reduction of cultural essentialism based on feminization/infantilization in the representation of refugees. On the other hand, it could also be traced back to a general tendency, always in biopolitical terms, to underestimate the female presence in the migration process or it could also be related to more "securitized" representations of refugees depicted as threat. Nevertheless, such a change in the representation of refugees does not necessarily mean that we are no longer in the presence of new 
stereotyped representation; but undoubtedly it is not a reduction of the complexity of the refugee figure as usually portrayed by the monolithic media image.

\section{Acknowledgments}

This paper stems from a larger research project, Imago migrantis, conducted by the Institute for Research on Population and Social Policies of Italian National Research Council (IRRPS-CNR). I would like to thank my colleague team members Adriana Valente, Valentina Tudisca, Loredana Cerbara, and Maria Girolama Caruso.

\section{References}

Agamben G (1998) Homo sacer: sovereign power and bare life. Stanford: Stanford University Press.

Agamben G (2000) Means without ends: notes on politics. Minneapolis: University of Minnesota Press.

Agier M (2005) Ordine e disordini dell'umanitario. Dalla vittima al soggetto politico [Order and disorder of the humanitarian. From the victim to the political subject]. Annuario di Antropologia 5(5): 49-65.

Agier M (2009) Le Camp comme limite et come espace politique. In Enformés dehors. Enquêtes sur le confinement des etrangers, C Makaremi and C Kobelinsky (eds.), 2740. Paris: Terra.

Altheide D (2000) L'analisi qualitativa dei media [Qualitative analysis of the media]. Rubbettino: Soveria Mannelli.

Arendt H (1951) The origins of totalitarianism. New York: Schocken Books.

Baines EK (2004) Vulnerable Bodies: Gender, the UN and the Global Refugee Crisis. Aldershot: Ashgate.

Barisione M. (2009) Comunicazione e società. Teoria, processi, pratiche del framing. [Communication and society. Theory, processes, practices of framing]. Bologna: il Mulino.

Barretta P, Milazzo G (eds) (2016) Notizie oltre i muri. Quarto rapporto Carta di Roma 2016 [News beyond the walls. Fourth report Carta di Roma 2016]. Pavia: Osservatorio di Pavia.

Berger PL, Luckmann T (1966) The Social Construction of Reality. London: Penguin Books.

Berry M, Garcia-Blanco I, Moore K (eds) (2015). Press coverage of the refugee and migrant crisis in the EU: A content analysis of five European countries. Cardiff: Cardiff School of Journalism, Media and Cultural Studies.

Binotto M, Bruno M, Lai V (eds) (2016) Tracciare confini. L'immigrazione nei media italiani [Drawing boundaries. Immigration in Italian media]. Milan: FrancoAngeli.

Bleiker R, Campbell D, Hutchison E, Nicholson X (2013) The visual dehumanisation of refugees. Australian Journal of Political Science, 48(4): 398-416.

Boltanski L. (1993) La souffrance à distance. Morale humanitaire, médias et politique. Paris: Métailié.

Boukala S, Dimitrakopoulou D (2017) Absurdity and the "Blame Game" Within the Schengen Area: Analyzing Greek (Social) Media Discourses on the Refugee Crisis. Journal of Immigrant \& Refugee Studies: 1-19. 
Bruno M (2014) Cornici di realtà. Il frame e l'analisi dell'informazione [Frames of reality. The frame and the information analysis]. Milan: Guerini e Associati.

Cagiano de Azevedo R, Paparusso A (2016) Le nuove migrazioni in Europa e nel Mediterraneo [New migrations in Europe and in the Mediterranean]. In Profughi [Refugees], C Bonifazi and M Livi Bacci (eds), 63-66. Florence: Associazione Neodemos.

Caniglia E (2009) La notizia. Come si racconta il mondo in cui viviamo [The news. How to tell the world in which we live]. Bari-Rome: Laterza.

Dal Lago A (1999) Non persone. L'esclusione dei migranti in una società globale [Nonpersons. The exclusion of migrants in a global society]. Milan: Feltrinelli.

Deuze M (2003) The web and its journalisms: considering the consequences of different types of newsmedia online. New media \& Society 5(2): 203-230.

Diken B, Lausten CB (2006) The camp. Swedish Society for Anthropology and Geography 88(4): 443-452.

Esses VM, Medianu S, Lawson AS (2013) Uncertainty, threat, and the role of the media in promoting the dehumanization of immigrants and refugees. Journal of Social Issues 69(3): 518-536.

European Journalism Observatory (2015) Come i giornali europei hanno trattato la crisi dei migranti [How European newspapers have treated the crisis of migrants]. Retrieved from https://bit.ly/1JnS2Fx. [Accessed 18 April 2018].

EUROSTAT (2016) Asylum and first time asylum applicants by citizenship, age and sex Annual aggregated data. Retrieved from https://bit.ly/2dItUGb [Accessed 27 April 2018].

Farr MR, Moscovici S (eds) (1984) Social representations. Cambridge: Cambridge University Press.

Foucault M (1975) Surveiller et punir. Naissance de la prison. Paris: Gallimard.

Frost T (2013) Giorgio Agamben. Legal, Political and Philosophical Perspectives. London: Routledge.

Gabrielatos C, Baker P (2008) Fleeing, sneaking, flooding. A corpus analysis of discursive constructions of refugees and asylum seekers in the UK press, 1996-2005. Journal of English Linguistics 36(1): 5-38.

Gemi E, Ulasiuk I, Triantafyllidou A (2013) Migrants and media newsmaking practices. Journalism Practice 7(3): 266-281.

Greussing E, Boomgaarden HG (2017) Shifting the refugee narrative? An automated frame analysis of Europe's 2015 refugee crisis. Journal of Ethnic and Migration Studies: 1-26.

Haaken JK, O'Neill M (2014) Moving images: Psychoanalytically informed visual methods in documenting the lives of women migrants and asylum seekers. Journal of Health Psychology 19(1): 79-89.

Hall S (1980) Encoding/decoding. In Culture, media, language, S Hall, D Hobson, A Lowe, P Willis (eds), 128-138. London: Hutchinson.

Harrell-Bond B (1999) The experience of refugees as recipients of aid. In Refugees: perspectives on the experience of forced migration, A Ager (ed), 136-168. London: Continuum.

Haslam N (2006) Dehumanization: An integrative review. Personality and Social Psychology Review 10(3): 252-264.

Hier SP, Greenberg JL (2002) Constructing a discursive crisis: risk, problematization and illegal Chinese in Canada. Ethnic and Racial Studies 25(3): 490-513.

Horsti K (2008) Europeanisation of public debate. Swedish and Finnish news on African migration to Spain. Javnost - The Public 15(4): 41-53.

Hyndman J (2000) Managing Displacement: Refugees and the Politics of 
Humanitarianism. Minneapolis: University of Minnesota Press.

Ibrahim Y, Howarth A (2016) Imaging the Jungles of Calais: media visuality and the refugee camp. Networking Knowledge 9(4): 1-22.

Johnson HL (2011) Click to donate: visual images, constructing victims and imagining the female refugee. Third World Quarterly 32(6): 1015-1037.

Jones RH (2012) Multimodal discourse analysis. In The encyclopedia of applied linguistics, CA Chapelle (ed), 20-33. Iowa: Blackwell Publishing.

Kapur R (2002) The tragedy of victimization rhetoric: resurrecting the "native" subject in international/post-colonial feminist legal politics. Harvard Human Rights Journal 15: $1-37$.

Kelly T (2013) A life less miserable?. Hau: Journal of Ethnographic Theory 3(1): 213-16.

Klocker N, Dunn KM (2003) Who's driving the asylum debate? Newspaper and government representations of asylum seekers. Media International Australia 109(1): 71-92.

Kopper GG, Kolthoff A, Czepek A (2000) Research review: online journalism - A report on current and continuing research and major questions in the international discussion. Journalism Studies 1(3): 499-512.

Leyens J-P, Paladino PM, Rodriguez-Torres R, Vaes J, Demoulin S, Rodriguez-Perez A, Gaunt R (2000) The emotional side of prejudice: The attribution of secondary emotions to ingroups and outgroups. Personality and Social Psychology Review 4(2): 186-197.

Machin D, Mayr A (2012) How to do critical discourse analysis: A multimodal introduction. London: Sage.

Malkki L (1996) Speechless emissaries. Refugees, humanitarism and dehistoricization. Cultural Anthropology 11(4): 377-404.

Maneri M (2009) I media e la guerra alle migrazioni [The media and the war against migration]. In Razzismo democratico [Democratic Racism], S Palidda (ed), 66-85. Milan: Agenzia X.

Maneri M (2011) Media discourse on immigration. The translation of control practices into the language we live by. In Racial criminalization of migrants in the 21st century, S Palidda (ed), 77-93. Farnham: Ashgate.

Meyers O (2002) Still Photographs, Dynamic Memories: A Study of the Visual Presentation of Israel s Past in Commemorative Newspaper Supplements. The Communication Review 5(3): 179-205.

Moscovici S (1988) Notes towards a description of social representations. European Journal of Social Psychology 18: 211-250.

Newman N, Fletcher R, Levy DAL, Nielsen RK (2016) Reuters Institutes Digital News Report 2016. Oxford: University of Oxford.

Nyers P (1999) Emergency or emerging identities? Refugees and transformations in world order. Millennium: Journal of International Studies 28: 1-26.

Ong WJ (1982) Orality and Literacy. The Technologizing of the Word. London and New York: Routledge.

Ortner SB (2016) Dark anthropology and its others Theory since the eighties. Hau: Journal of Ethnographic Theory 6(1): 47-73.

Papadopoulou L (2015) La crisi dei migranti nei media greci [The crisis of migrants in the Greek media]. Retrieved from https://bit.ly/2DBZRjB [Accessed 10 March 2018].

Pavlik J (2001) Journalism and new media. New York: Columbia University Press.

Quinsaat S (2014) Competing news frames and hegemonic discourses in the construction of contemporary immigration and immigrants in the United States. Mass Communication and Society 17(4): 573-596.

Rahola F (2003) Zone definitivamente temporanee. I luoghi dell'umanità in eccesso 
[Definite temporary areas. The places of humanity in excess]. Verona: Ombre corte.

Rahola F (2005) Rappresentare "gli spazi fuori". Note per un'etnografia dei campi profughi [Representing "spaces outside". Notes for an ethnography of refugee camps]. Annuario di Antropologia 5: 67-83.

Rajaram PK (2002) Humanitarianism and representations of the refugee. Journal of Refugee Studies 15:247-264.

Robbins J (2013) Beyond the suffering subject: Toward an anthropology of the good. Journal of the Royal Anthropological Institute 19(3): 447-62.

Royce TD, Bowcher WL (eds) (2007) New directions in the analysis of multimodal discourse. Mahwah: Lawrence Erlbaum Associates.

Sayad A (1999) La double absence. Des illusions de l'émigré aux souffrances de l'immigré. Paris: Libre, Seuil.

Sbriscia D (2001) Socio-logica del senso comune [Socio-logic of common sense]. Sociologia della comunicazione 17(31): 101-114.

Silveira C (2016) The Representation of (illegal) migrants in the British news. Networking Knowledge 9(4): 1-16.

Sorrentino C (2002) Il giornalismo. Cos'è e come funziona [Journalism. What is and how it works]. Rome: Carocci.

Sorrentino C (ed) (2006) Il campo giornalistico: i nuovi orizzonti dell'informazione [The journalistic field: the new horizons of information]. Rome: Carocci.

Steimel SJ (2010) Refugees as people: the portrayal of refugees in American human interest stories. Journal of Refugee Studies 23(2): 219-237.

Szörényi A (2006) The images speak for themselves? Reading refugee coffee-table books. Visual Studies 21(1): 24-41.

Triandafyllidou A (2009) The Mohammed cartoons crisis in the British and Greek press. Journalism Studies 10(1): 36-53.

Tuchman G (1978) Making news: a study in the construction of reality. New York: Free Press.

Tudisca V, Pelliccia A, Caruso MG, Cerbara L, Valente A (2017) La rappresentazione dei migranti nelle testate giornalistiche online europee: un'analisi pilota [The representation of migrants in European online newspapers: a pilot analysis]. In Migrazioni e integrazioni nell'Italia di oggi [Migrations and integrations in today's Italy], C Bonifazi (ed), 337-351. Rome: CNR-IRPPS e-Publishing.

UNHCR (2010) Convention and protocol relating to the status of refugees. Retrieved from http://www.unhcr.org/3b66c2aa10 [accessed 19 August 2018].

UNHCR (2016a) Superata la quota di 300.000 arrivi nel Mediterraneo dall'inizio dell'anno. L'UNHCR chiede con urgenza maggiori canali di ammissione per i rifugiati e velocizzare i ricollocamenti da Italia e Grecia [The quota of 300.000 arrivals in the Mediterranean has been exceeded since the beginning of the year. UNHCR urgently calls for more admission channels for refugees and relocation from Italy and Greece]. Retrieved from https://bit.ly/2NAJXub [Accessed 23 April 2018].

UNHCR (2016b) L'UNHCR ridefinisce il suo ruolo in Grecia con l'entrata in vigore dell'accordo UE-Turchia [UNHCR redefines its role in Greece with the entry into force of the EU-Turkey agreement]. Retrieved from https://bit.ly/294Qest [Accessed 11 March 2018].

Van Gorp B (2005) Where is the frame? Victims and intruders in the Belgian press coverage of the asylum issue. European Journal of Communication 20(4): 484-507.

Van Aken M (2005) Introduzione [Introduction]. Annuario di Antropologia 5: 5-14.

Vieira I (2016) The construction of the Mediterranean refugee problem from the Italian digital press (2013-2015): emergencies in a territory of mobility. Networking Knowledge 9(4): 1-19. 